\title{
PENGARUH KECEPATAN LAYANAN DAN KERAMAHAN LAYANAN TERHADAP KEPUASAN PELANGGAN DIRUMAH KOPI LAMONGAN
}

\author{
Moh Azus shony Azar \\ Achmad Efendi \\ Fakultas Ekonomi Universitas Islam Darul Ulum Lamongan \\ azus@unisda.ac.id \\ Achmad_Efendi@gmail.com
}

\begin{abstract}
This research to analyze the effect of service speed and service friendliness on the satisfaction of Lamongan coffee house customers. The sample in this study were 100 respondents. Data collection method in this study is questionnaire and documentation study. The method of data analysis uses descriptive quantitative methods, namely with multiple linear regression analysis and classical assumption tests.Based on the $\mathrm{F}$ test results obtained F-count is greater than F-count 204.254> F table value $=3.09$, service speed and service friendliness together have a positive effect on customer satisfaction. Based on the T Test Service speed (X1) has a positive and significant effect on customer satisfaction, Service friendliness (X2) has a positive and significant impact on customer satisfaction. Service speed is the most influential variable on customer satisfaction. Through testing the Determination Coefficient by adjusted R Square (R2) $80.4 \%$, customer satisfaction can be explained by variable service speed and service friendliness, while $19.6 \%$ performance can be explained by other variables not examined by this study.
\end{abstract}

Keywords: Service speed, service friendliness and customer satisfaction

Abstrak: Penelitian ini bertujuan menganalisa pengaruh kecepatan layanan dan keramahan layanan terhadap kepuasan pelanggan rumah kopi Lamongan. Sampel dalam penelitian ini adalah 100 responden. Metode pengumpulan data dalam penelitian ini adalah kuesioner dan studi dokumentasi. Metode analisis data meenggunakan metode deskriptif kuantitaif yaitu dengan Analisis Regresi Linear Berganda dan Uji Asumsi klasik.Berdasarkan uji F diperoleh hasil F-hitung lebih besar daripada F-hitung 204,254 > nilai F tabel = 3,09, Kecepatan layanan dan keramahan layanan secara bersama-sama berpengaruh positif terhadap kepuasan pelanggan. Berdasarkan Uji T Kecepatan layanan (X1) berpengaruh secara positif dan signifikan terhadap kepuasan pelanggan, Keramahan layanan (X2) berpengaruh secara positif dan signifikan terhadap kepuasan pelanggan. Kecepatan layanan adalah variabel yang paling berpengaruh terhadap kepuasan pelanggan. Melalui pengujian Koefisien Determinasi diproleh adjusted R Square (R2) 80,4 \%, kepuasan pelanggan dapat dijelaskan oleh variabel kecepatan layanan dan keramahan layanan , sedangkan 19,6\% kinerja dapat dijelaskan oeh variabel lainnya yang tidak diteliti penelitian ini.

Kata kunci : Kecepatan layanan, Keramahan layanan dan Kepuasan pelanggan

\section{PENDAHULUAN}

Era globalisasi ini persaingan bisnis menjadi sangat tajam baik di pasar domestik maupun pasar internasional atau global. Salah satu cara memenangkan persaingan adalah perusahaan harus mampu memberikan kepuasan kepada para pelanggannya, misalnya dengan memberikan produk yang mutunya lebih baik, harganya lebih murah, penyerahan 
produk yang lebih cepat dan pelayanan yang lebih baik dari pada pesaingnya akan menyebabkan pelanggan menjadi lebih puas (Nugroho dan Puriarta, 2011:28).

Lamongan merupakan salah satu kota bisnis di Indonesia, yang mayoritas penduduknya disibukan dengan rutinitas yang lumayan padat. Namun sewaktuwaktu kejenuhan dari rutinitas yang padat itu menimbulkan kecenderungan melepas lelah dengan berbagai cara di antarannya berkumpul dengan teman ataupun hanya duduk disebuah tempat yang dianggap nyaman, misalnya saja di warung kopi atau Rumah Kopi.

Mengkonsumsi kopi telah menjadi salah satu kebutuhan dan gaya hidup (life style) masyarakat saat ini. Kedai kopi menjadi tujuan yang sangat diminati terutama kalangan muda untuk sekedar bersantai atau berkumpul dengan teman. Tidak hanya kalangan muda, kalangan pebisnis pun sering menghabiskan waktunya di kedai kopi untuk membahas rencana bisnisnya atau untuk bertemu dengan rekan kerjanya. Dari banyaknya permintaan akan kopi membuat para wiraswasta tertarik untuk membuka usaha kedai kopi sehingga saat ini banyak bermunculan kedai kopi yang membuat persainagn semakin ketat. Dalam menghadapi persaingan yang semakin ketat ini pengelolaan kedai kopi dituntut untuk lebih tanggap mengetahui apa saja yang menjadi kebutuhan, keinginan serta selera konsumen di masa sekarang dan di masa akan datang (Indah Sevia Wulandari, 2012).

Rumah Kopi didirikan pada tanggal 14 April 2009, menurut Pimpinan Rumah Kopi awalnya Rumah Kopi ini menggunakan nama "Kopi Holik" namun penggunaan nama tersebut dirasa kurang menarik minat konsumen, sehingga pemakainan nama Kopi Holik tidak bertahan lama, sampai tercetus ide dari pemilik untuk mengganti nama "Rumah Kopi”. Awal berdirinya Rumah Kopi hanya mengunakan lahan parkir yang ada di ruko Made, kondisi seperti ini dirasa kurang efisien karena tidak adanya tempat indoor saat cuaca hujan datang, dalam waktu kurang lebih setahun Rumah Kopimulai menyewa ruko dengan menambah modal usaha dan mempunyai tempat yang cukup luas ada outdoor dan 2 lantai indoor yang lokasinya di Jalan. Mastrip 48 Lamongan Kota.

Rumah Kopi memulai waktu operasinya dari pukul 10:00 - 02:00 WIB. Jumlah karyawan yang bekerja ada 30 orang, Menurut Pimpinan Rumah Kopi, dengan waktu operasi \pm 16 jam dan jumlah karyawan 30 orang itu dirasa cukup untuk memberikan pelayanan yang maksimal, baik dan memuaskan kepada setiap pengunjung yang datang. Rumah Kopi ramai dikunjungi dijam 19:00 WIB, target pasar dari Rumah Kopi ini adalah kalangan menengah ke bawah. Banyaknya Rumah Kopi yang menyediakan produk yang sama, membuat Rumah Kopi manggunakan strategi yang berbeda dengan Rumah Kopi lainnya yaitu dengan memberikan pelayanan yang maksimal bagi pengunjung, mulai dari menu yang beraneka ragam seperti Kopi sebagai produk utama, Aneka snack, Juice, aneka makanan meliputi, nasi goreng, spagethi, steak, chicken khungpow, bakmi jawa, roti bakar, dll, dengan harga yang terjangkau, serta adanya sarana live musik atau acoustic di Rumah Kopi ini yang jarang dimiliki oleh Rumah Kopi lainnya, event live musik didapat dari sponsor perusaan rokok ternama yaitu Sampoerna, dan event ini tidak setip hari ditampilkan tergantung dari pihak sponsor ingin menyelenggarakan atau tidak, adanya LCD proyektor untuk menonton bola bersama.

$\begin{array}{lrr}\text { Berdasarkan } & \begin{array}{r}\text { latarbelakang } \\ \text { mengambil diatas } \\ \text { judul }\end{array} \\ \text { penulis tertarik } & \begin{array}{r}\text { KECEPATAN } \\ \text { "PENGARUH }\end{array} \\ \text { LAYANAN } & \text { DAN } & \text { KERAMAHAN } \\ \text { LAYANAN TERHADAP KEPUASAN }\end{array}$


PELANGGAN DIRUMAH KOPI LAMONGAN"

Berdasarkan latar belakang, maka dirumuskan masalah penelitian sebagai berikut :

1.Adakah pengaruh secara Parsial kecepatan layanan dan keramahan terhadap kepuasan Pelanggan Rumah Kopi Lamongan?

2.Adakah pengaruh secara simultan kecepatan layanan dan keramahan terhadap kepuasan Pelanggan Rumah Kopi Lamongan?

3.Variabel manakah yang paling berpengaruh kecepatan layanan dan keramahan terhadap kepuasan Pelanggan Rumah Kopi Lamongan?

\section{KAJIAN PUSTAKA}

\subsection{Kecepatan}

Kecepatan yaitu suatu kemampuan untuk pelayanan yang cepat (responsif). Pelayanan adalah suatu bagian atau urutan yang terjadi dalam interaksi langsung antara seseorang dengan orang lain atau mesin secara fisik dan meyediakan kepuasan pelanggan.

Dalam kamus besar bahasa Indonesia pelayanan adalah usaha melayani kebutuhan orang lain, sedangkan melayani adalah membantu menyiapkan (mengurus) apa yang diperlukan seseorang. (Navri, 2010 ; 105).

Dalam kehidupan sehari-hari kata antrian bukan suatu kata yang sering bagi masyarakat kita, seorang atau suatu instansi baik swasta maupun instansi pemerintah dalam kegiatan operasionalnya sangat pentig untuk memberikan suatu service atau pelayanan kepada konsumen, salah satunya dengan cara memberikan kecepatan layanan yang sangat memuaskan kepada konsumen. Dengan demikian yang menjadi tujuan utama pada pelayanan kecepatan layanan atau sering disebut dengan antrian ialah untuk mencapai keseimbangan antara ongkos pelayanan dengan ongkos yang disebabkan oleh adanya waktu menunggu tersebut. Walaupun begitu pada sistim ini akan menyumbangkan informasi penting yang diperlukan untuk membuat keputusan seperti itu dengan cara membuat karakteristik dari masalah yang sedang dihadapi oleh instansi tersebut.

Jadi dapat disimpulkan bahwa kecepatan pelayanan adalah pelayanan yang responsif tanpa melihat status, mampu berinteraksi dengan orang lain. Kecepatan diberikan kepada seluruh pelanggan Rumah Kopi dalam meningkatkan pelayanannya.

\section{Pengertian Kenyamanan}

Merupakan suatu penilaian dari perasaan yang timbul akibat rangsangan dari lingkungan yang memberikan keadaan yang stabil, cukup baik, puas, dan pengalaman repetitif untuk kelanjutannya. Untuk suatu lingkungan organisasi arti kenyamanan dapat berupa :

a) Kelengkapan dari penyediaan fasilitas adalah unsur utama, sehingga para pengguna memiliki sarana yang lengkap sebagai alat bantu yang cukup baik dalam mendukung pelaksanaan program pembelajaran.

b) Perawatan yang baik dari seluruh fasilitas yang ada, dengan demikian selalu dalam

keadaan baik $\begin{aligned} & \text { dan } \\ & \text { seluruh }\end{aligned}$
fungsi

penggunaannya dapat bermanfaat hingga optimal dan pada akhirnya memberikan kepuasan serta bagi pengguna.

c) Product Knowledge serta bantuan dan pelayanan dari seluruh karyawan bagi masyarakat untuk informasi serta ketidakjelasan lainnya dengan ramah, sopan dan 
kecepatan informasi yang diberikan.

d) Suasana lingkungan disekitar yang yang hijau, teduh dan asri memberikan kesejukan, keteduhan serta relaksasi dalam arti tersendiri bagi pengguna lingkungan. Disamping fungsi lain sebagai pelindung dari bising, debu yang berterbangan dan filter dari sinar matahari.

e) Kebersihan dari seluruh fasilitas haruslah terjaga dengan baik, karena hal ini akan memberikan peran menciptakan suatu budaya pembiasaan bagi siswa serta memberikan kesan penghargaan tersendiri bagi seluruh pengguna dengan perduli terhadap penciptaan lingkungan yang sehat.

Jadi dapat disimpulkan bahwa kenyamanan merupakan perwujudan lengkapnya fasilitas utama dan penunjang, segala yang diperlukan selalu tersedia, kebersihan yang selalu terjaga dan segala informasi pelayanan tersedia.

2.Ketepatan Waktu Layanan

Dalam pelayanan terhadap konsumen sangat di utamakan, termasuk dalam ketepatan waktu layanan, karena ketepatan waktu layanan bagi konsumen sangat diperhatikan, jika layanan memperhatikan janji yang sudah disepakati oleh konsumen haruslah tepat, jadi konsumen sendiri akan merasa puas dan senang akan ketepatan waktu dalam layanan.

3 Struktur Dasar Model Kecepatan Layanan Atau Sistem Antrian

Proses yang terjadi pada model layanan kecepatan layanan dapat dijabarkan sebagai berikut :

"Unit langganan yang memerlukan pelayanan akan di turunkan dengan memasuki sistem dan akan ikut dalam proses waktu tertentu. Anggota antrian ini akan dipilih untuk dilayani yang disebut dengan "Disiplin pelayanan", pelaksanaan pelayanan di butuhkan cara tertentu setelah itu unit-unit langganan tersebut akan meninggalkan sistim antrian tersebut". (Tjutju Tarliah Dimyati, Ahmad Dimyati: 2012 : 350).

Oleh karena suatu instansi baik instansi pemerintah maupun instansi swasta harus mempunyai kebijaksanaan tertentu yang sesuai dengan kondisi dan keadaan yang pada instansi tersebut. Karena pada setiap masing-masing instansi berbeda cara dalam memberikan pelayanan kepada konsumennya

\section{Keramahan}

Menurut Heri Kuswara " Ramah adalah sikap santun terhadap semua orang agar orang lain merasakan kenyamanan dan perasaan senang saat bersama kita. Bersikap ramah dan baik ternyata belum cukup bagi karyawan dalam menjalankan tugasnya. Sikap dan perilaku dalam dunia bisnis juga menjadi salah satu faktor untuk mengembangkan dan memajukan usaha “. (Kuswara, 2009 ; 57). Adapun sikap dan perilaku yang harus dilakukan, baik itu oleh pengusaha maupun oleh karyawan adalah sebagai berikut.

a) Jujur dalam bertindak dan bersikap Sikap jujur merupakan modal utama dalam melayani pelanggan. Kejujuran inilah yang akan menumbuhkan kepercayaan konsumen terhadap pelayanan yang diberikan.

b) Rajin, tepat waktu dan tidak malas. Sifat ini harus dimiliki oleh seorang pengusaha dan juga para karyawannya dalam melayani pelanggan. Selain itu, mereka juga dituntut untuk cekatan dalam bekerja, pantang menyerah, selalu ingin tahu, tidak mudah putus asa serta memiliki sifat malas.

c) Selalu murah senyum. 
Dengan senyum, akan lebih mudah bagi karyawan dalam membujuk pelanggan agar ia menyukai produk atau perusahaan. Para pelanggan biasanya akan tersanjung dan merasa dihargai dengan senyum yang ditunjukan karyawan.

d) Lemah lembut dan ramah tamah.

Pada saat berbicara dengan para pelanggan, ada baiknya dengan suara yang lemah lembut yang didukung oleh sikap ramah. Sikap seperti itu, dapat menarik minat tamu dan membuat pelanggan betah berhubungan dengan perusahaan.

e) Sopan santun dan hormat.

Dalam memberikan pelayanan kepada pelanggan hendaknya selalu dengan sopan dan hormat. Dengan demikian, pelanggan juga akan menghormati pelayanan yang diberikan karyawan tersebut.

f) Selalu ceria dan pandai bergaul.

Sikap seperti itu akan memecahkan kekakuan yang ada. Dengan sikap pandai bergaul, pengusaha atau karyawan akan cepat akrab dengan para pelanggan sehingga diharapkan segala urusan menjadi lebih lancar.

g) Fleksibel dan suka menolong pelanggan.

h) Dalam menghadapi pelanggan, karyawan harus dapat memberikan pengertian. Selain itu, juga diharapkan dapat memberikan pertolongan kepada pelanggan yang mengalami kesulitan.

i) Serius dan memiliki rasa tanggung jawab.

Dalam melayani pelanggan, pengusaha atau karyawan harus melakukannya dengan serius dan dengan sepenuh hati. Mereka juga harus bertanggung jawab terhadap pekerjaan agar pelanggan merasa puas terhadap pelayanan yang diberikan.

j) Rasa memiliki perusahaan yang tinggi

Pengusaha dan karyawan harus merasa memiliki setiap unsur perusahaan. Dengan sikap seperti itu, diharapkan setiap pihak dapat termotivasi dalam berusaha mengembangkan dan memajukan perusahaan. Selain sifat tersebut, pemilik dan karyawan juga diharapkan memiliki jiwa pengabdian, loyal, dan setia kepada perusahaan.

k) Gunakan norma-norma agama, setiap agama memiliki aturan yang difirmankan tuhan.

Jadi dapat disimpulkan bahwa nilainilai sikap dan perilaku setiap karyawan harus tercermin di dalam setiap bentuk pelayanan ketika berhubungan langsung dengan konsumen guna memberikan kepuasan yang maksimal bagi konsumen.

\section{3 . Pengertian Pelayanan}

Menurut H. A. S. Moenir, pelayanan diartikan sebagai berikut : Setiap kegiatan yang dilakukan oleh pihak lain yang ditujukan guna memenuhi kepentingan orang banyak. Namun tidak berarti bahwa pelayanan itu sifatnya kolektif karena melayani kepentingan perorangan pun asal kepentingan itu termasuk dalam rangka pemenuhan hak dan kebutuhan bersama yang telah diatur termasuk dalam pengertian pelayanan (Moenir, $2012 ; 12$ ). Sedangkan pengertian lain tentang pelayanan yang didasarkan pada proses, yaitu proses pemenuhan kebutuhan melalui efektifitas orang lain yang langsung dinamakan pelayanan.

Jadi dapat disimpulkan pelayanan adalah segala kegiatan yang dilakukan oleh pihak lain untuk memenuhi kepentingan dan kebutuhan orang lain, sehingga konsumen merasakan kepuasan dan merupakan tujuan dari perusahaan untuk memperoleh 
keuntungan. Sedangkan standarisasi pelayanan merupakan hal - hal yang harus dijalankan dalam melayani kepentingan konsumen yang didasarkan pda proses guna pemenuhan kebutuhan konsumen, sehingga konsumen merasa dihargai atas pelayanan tersebut.

\section{METODE PENELITIAN}

Metode yang digunakan dalam menyusun penelitian ini adalah metode penelitian kuantitatif. Adapun jenis penelitiannya adalah ekspalatory research suatu metode dalam meneliti status sekelompok manusia, suatu obyek, suatu set kondisi, suatu sistem pemikiran ataupun suatu kelas peristiwa pada masa sekarang. (Moh. Nazir, 2011:63)

\section{Populasi}

Populasi merupakan keseluruhan dari kumpulan elemen yang memiliki sejumlah karakteristik umum, yang terdiri dari bidang-bidang untuk diteliti atau keseimbangan kelompok dari orang-orang, peristiwa atau barang-barang yang diminati oleh peneliti untuk diteliti. (Malhotra dikutip oleh Widayat dan Amirullah, 2002;52). Populasi pada penalitian ini adalah jumlah pelanggan Rumah Kopi Lamongan selama 6 bulan terakhir berjumlah 5.988 orang

\section{Sampel}

Sampel ialah bagian dari jumlah dan karakteristik yang dimiliki oleh populasi tersebut. Dalam penelitian ini tidak seluruh anggota populasi diambil, melainkan hanya sebagian dari populasi Penelitian ini mengambil sampel konsumen selama 6 bulan. Dalam penarikan jumlah ukuran sampel, apabila populasinya diketahui secara pasti jumlahnya maka dapat digunakan teknik atau rumus Solvin. Menurut Solvin dalam Muhamad (2008; 180) dalam penentuan jumlah sampel dapat digunakan rumus sebagai berikut:

$$
\begin{aligned}
& \mathrm{n}=\mathrm{N} /(1+\mathrm{N} . \mathrm{e} 2) \\
& \text { Keterangan: }
\end{aligned}
$$

$$
\begin{gathered}
\mathrm{n}=\text { ukuran sampel, } \\
\mathrm{N}=\text { ukuran populasi. } \\
\mathrm{e}=\text { persen }
\end{gathered}
$$

kelonggaran

ketidaktelitian karena kesalahan pengambilan sampel yang masih ditolelir atau diinginkan, dalam penelitian ini peneliti mengambil kelonggaran $10 \%$.

Penghitungan dari rumus ini adalah sebagai berikut:

$$
\begin{aligned}
& \mathrm{n}=\mathrm{N} /(1+\mathrm{N} . \mathrm{e} 2) \\
& =115.988 /(1+5.988 * \llbracket(10 \%) \rrbracket 2) \\
& =115.988 / 60,24 \\
& =99,64 \text { responden/sampel. }
\end{aligned}
$$

Jadi, berdasar perhitungan diatas diperoleh jumlah sampel yang digunakan dalam penelitian ini adalah sebanyak 100 responden

Tehnik Pengambilan sampel Sampel

Dalam penelitian ini digunakan metode pengambilan sampel dengan cara Purposive Sampling dan Convinience Sampling.

Purposive Sampling adalah pemilihan sampel pada konsumen berdasarkan tujuan, sedangkan Convinience Sampling adalah pemilihan sampel kepada konsumen yang mudah ditemui. Sugiyono (2012:322)

Variabel penelitian yang ada di penelitian ini adalah :

a. Variabel Bebas Terdiri dari

1. Kecepatan Layanan (X1) adalah suatu kemampuan untuk pelayanan yang cepat (responsif) Navri ( 2010: 110).dengan Indikator sebagai berikut :
a. Standar waktu
b. tuntas
c. efisien dan efektif
d. konsisten
e. Perbaikan.

2. Keramahan (X2) adalah sikap santun terhadap semua orang agar orang lain merasakan kenyamanandan perasaan senang saat bersama kita (Kuswara, 2009:71). dengan indikator sebagai berikut;
a. Sikap santun

b. Rasa senang 
c. Menyapa

d. Respon positif

e. Terkesan baik

b. Variabel Terikat (Y). Kepuasan Pelanggan Kepuasan pelanggan hanya dapat tercapai dengan memberikan pelayanan yang berkualitas kepada konsumennya (Kotler, 2013:89) , indikator terdiri dari :
a. Layanan berkualitas
b. Tetap puas
c. Penghargaan
d. Tindakan positif
e. Dampak positif

\section{Analisis Data}

1. Uji Instrumen Penelitian

Instrumen penelitian ini memakai alat bantu kuesioner dalam mengumpulkan data primer, untuk pengujian penelitian ini digunakan uji:

a.Uji Validitas

Menurut Ghozali $(2012 ; 135)$

uji validitas digunakan untuk mengukur sah atau valid tidaknya suatu kuesioner. Penelitian di katakan valid jika mampu mengukur yang diinginkan serta dapat mengungkapkan data dari variabel yang diteliti secara tepat

Uji signifikansi dilakukan dengan membandingkan nilai $r$ hitung dengan nilai $r$ tabel untuk df $=\mathrm{n}-\mathrm{k}$ dalam hal ini $\mathrm{n}$ adalah jumlah sample dan $\mathrm{k}$ adalah jumlah variabel bebas. Jika $r$ hitung (dapat dilihat dalam kolom corected itemtotal corelation lebih besar dari 0,3) atau lebih besar dari $r$ tabel (dilihat dari r product moment) dan nilai $r$ positif. Maka butir atau pertanyaan tersebut dikatakan valid

b. Uji Reabilitas

Menurut Ghozali $(2012 ; 132)$ Suatu kuesioner dikatakan reliabel atau handal jika jawaban seseorang terhadap pernyataan adalah konsisten atau stabil dari waktu ke waktu.
Sugiyono

menyatakan bahwa "pengujian reliabilitas yaitu membandingkan nilai Alpha dengan nilai tabel $\mathrm{r}$ product moment untuk menghasilkan data yang dapat dipercaya dan dapat di andalkan. Bila nilai Alpha yang diperoleh lebih besar dari angka kritis dalam tabel $r$ maka data tersebut reliable.

Pengujian validitas item masing-masing perubah penelitian ini menggunakan komputer melalui program SPSS 22.0 for windows.

2.Uji Asumsi Klasik

a. Multikolinearitas

. Uji multikolinearitas dalam penelitian ini adalah dengan melihat nilai Inflation Factor (VIF) pada model regresi. Menurut Santoso dalam Priyatno (2010:81) "pada umumnya jika VIF lebih besar dari 5, maka variabel tersebut mempunyai persoalan multikolinearitas dengan variabel bebas lainnya".

b. Heteroskedastisitas

Priyatno (2010:83) mengemukakan bahwa :

Heteroskedastisitas adalah keadaan dimana terjadi ketidaksamaan varian dari residual untuk semua pengamatan pada model regresi. Uji heteroskedastisitas digunakan untuk mengetahui ada atau tidaknya ketidaksamaan varian dari residual pada model regresi.

Dasar pengambilan keputusan :

1. Jika ada pola tertentu, seperti titik-titik (poin-poin) yang ada membentuk suatu pola tertentu yang teratur (bergelombang, melebar kemudian menyempit), maka telah terjadi heteroskedastisitas.

2. Jika tidak ada pola yang jelas, serta titik-titik menyebar di atas dan di bawah angka 0 pada sumbu $\mathrm{Y}$, maka tidak terjadi heteroskedastisitas.

c. Uji Autokolerasi 
Uji Autokorelasi bertujuan menguji apakah dalam suatu model regresi linier ada korelasi antara kesalahan penggangu pada periode $t$ dengan kesalahan pada periode $\mathrm{t}-1$ (sebelumnya).Jika terjadi korelasi, maka dinamakan ada problem autokorelasi. Autokorelasi muncul karena observasi yang berurutan spanjang waktu berkaitan satu sama lain. Masalah ini timbul karena residual (kesalahan pengganggu) tidak bebas dari satu observasi ke observasi lainnya. Hal ini sering ditemukan pada data runtut waktu (time series) karena "gangguan" pada individu/kelompok yang sama pada periode berikutnya. (Ghozali, 2018:111)

Durbin Watson akan dibandingkan dengan DW tabel dengan kriteria sebagai berikut:

- Jika DW > 4 maka ada autokorelasi

- Jika DW < 4 Maka tidak ada autokorelasi

d. Uji normalitas bertujuan untuk menguji apakah dalam model regresi,variabel pengganggu atau residual memiliki distribusi normal.(Ghozali, 2018:161).

- Jika data (titik) menyebar disekitar dan mengikuti arah garis diagonal maka model regresi memenuhi asumsi normalitas.

- Jika data menyebar jauh dari diagonal dan atau tidak mengikuti arah garis diagonal maka model regresi tidak memenuhi asumsi normalitas.

2. Regresi linier berganda

Yaitu untuk menguji atau melakukan estimasi dari suatu permasalahan yang terdiri lebih dari satu variabel bebas. Secara umum persamaan regresi linier berganda dapat dituliskan sebagai berikut:

$Y=\beta_{0}+\beta_{1} X_{1}+\beta_{2} X_{2}+e$

Keterangan:

$$
\begin{array}{ll}
\mathrm{Y} & =\text { Kepuasan Pelanggan } \\
\mathrm{X}_{1} & =\text { Kecepatan Layanan } \\
\mathrm{X}_{2} & =\text { Keramahan }
\end{array}
$$

$$
\begin{aligned}
\beta_{1} \ldots \beta_{5} & =\text { Koefisien regresi } \\
& \text { variabel } \mathrm{x} 1 \text { sampai } \mathrm{x} 2 \\
\mathrm{e} & =\text { Kesalahan penggangu } \\
& (\text { error disturbance) } \\
& (\text { Sugiyono, 2010:221) }
\end{aligned}
$$

4. Uji F (Uji Serempak)

Uji ini digunakan untuk mengetahui pengaruh bersama-sama variabel bebas terhadap varibel terikat. Dimana Fhitung> Ftabel, maka H1 diterima atau secara bersama-sama variabel bebas dapat menerangkan variabel terikatnya secara serentak. Sebaliknya apabila Fhitung < Ftabel, maka H0 diterima atau secara bersama-sama variabel bebas tidak memiliki pengaruh terhadap variabel terikat. Untuk mengetahuinya digunakan probability sebesar 5\% $(\alpha=0,05)$.

- Jika sig > á $(0,05)$, maka H0 diterima $\mathrm{H} 1$ ditolak.

- Jika sig < ́́ $(0,05)$, maka H0 ditolak H1 diterima.

\section{Uji t (Uji Parsial)}

Uji ini digunakan untuk mengetahui signifikansi dari pengaruh variabel independen terhadap variabel dependen secara individual dan menganggap dependen yang lain konstan. Signifikansi pengaruh tersebut dapat diestimasi dengan membandingkan antara nilai ttabel dengan nilai thitung.

Apabila nilai thitung > ttabel maka variabel independen secara individual mempengaruhi variabel independen, sebaliknya jika nilai thitung $<$ ttabel maka variabel independen secara individual tidak mempengaruhi variabel dependen.

thitung > ttabel berarti $\mathrm{HO}$ ditolak dan menerima $\mathrm{H} 1$

thitung $<$ ttabel berartiH0 diterima dan menolak $\mathrm{H} 1$

Uji $\mathrm{T}$ juga bisa dilihat pada tingkat signifikansinya:

- Jika tingkat signifikansi $<0,05$, maka $\mathrm{H} 0$ ditolak dan $\mathrm{H} 1$ diterima 
- Jika tingkat signifikansi > 0,05, maka $\mathrm{H} 0$ diterima dan $\mathrm{H} 1$ ditolak

6. Uji Koefisien Determinasi ( R2 )

Uji ini untuk mengetahui besarnya deregulasi audit variabel bebas dan variabel tidak bebas secara bersama-sama. Dalam beberapa model biasanya perhitungan R2 adalah kurang dari 1 tetapi yang sering terjadi adalah R2 berada antara 0,2 sampai 0,8 .

\section{HASIL PENELITIAN}

1. Karakteristrik Responden

a. Karakteristik Responden berdasarkan jenis kelamin.

Dapat diketahui bahwa Hasil tersebut dapat dilihat dari jumlah responden pria yaitu sebanyak 72 responden atau $72 \%$ dan sebanyak 28 responden atau $28 \%$ adalah Wanita .

b. Karakteristik resonden berdasarkan usia Responden diketahui yang minum kopi di rumah kopi Lamongan memiliki rata-rat usia antara 20-30 tahun. Hal ini menunjukkan bahwa usia seorang pelanggan berada dalam kisaran tersebut sehingga mereka dapat memiliki keputusan yang sesuai dengan karakter masing-masing. hal ini dapat disimpulkan bahwa usia antara 20-30 tahun sebanyak 35 orang atau $35 \%$, sedangkan usia 25-30 tahun sebanyak 32 oarang atau $32 \%$, sedangkan usia diatas 30 tahun sebanyak 33 orang atau 33\%,

\section{c.Karakteristik resonden pendapatan}

Responden responden jumlah terbesar adalah responden dengan Penghasilan per bulan Rp 1.500.000$\mathrm{Rp}$ 2.000.000 yaitu sebanyak 35 responden atau 35\%, sedangkan jumlah Penghasilan responden perbulan Rp 2.000.000-Rp 3.000.000 sebanyak 32 orang atau (32\%), tingkat Penghasilan pelanggan lebih besar dari Rp 3.000.000 sebanyak 33 orang dengan persentase $33 \%$, Berdasarkan dari informasi diatas, bahwa responden yang paling banyak melakukan keputusan minum kopi di rumah kopi Lamongan Adalah responden yang berpenghasilan antara dari Rp. 1.500 .000 - Rp. 2.000 .000

\section{Analisis Data}

a. Uji Validitas berikut ini

Uji validitas digunakan untuk melihat valid tidaknya masingmasing instrumen

1.Variabel X1

\begin{tabular}{|l|r|r|r}
\hline & $\begin{array}{c}\text { Scale Mean if ltem } \\
\text { Deleted }\end{array}$ & $\begin{array}{c}\text { Scale Variance if ltem } \\
\text { Deleted }\end{array}$ & $\begin{array}{c}\text { Corrected Item-Total } \\
\text { Correlation }\end{array}$ \\
\hline X1.1 & 16,37 & 6,902 &, 356 \\
X1.2 & 16,49 & 3,768 &, 761 \\
X1.3 & 16,54 & 3,564 &, 776 \\
X1.4 & 16,43 & 3,743 &, 809 \\
X1.5 & 16,41 & 4,002 &, 656 \\
\hline
\end{tabular}

2. Variabel X2

\begin{tabular}{|l|r|r|r|}
\hline & $\begin{array}{c}\text { Scale Mean if Item } \\
\text { Deleted }\end{array}$ & $\begin{array}{r}\text { Scale Variance if Item } \\
\text { Deleted }\end{array}$ & $\begin{array}{c}\text { Corrected Item-Total } \\
\text { Correlation }\end{array}$ \\
\hline X2.1 & 16,65 & 6,775 &, 722 \\
X2.2 & 16,84 & 6,398 &, 766 \\
X2.3 & 16,67 & 6,567 &, 821 \\
X2.4 & 16,61 & 6,382 &, 829 \\
X2.5 & 16,75 & 6,876 &, 733 \\
\hline
\end{tabular}

3.Variabel Y

\begin{tabular}{|l|r|r|r|}
\hline & $\begin{array}{c}\text { Scale Mean if Item } \\
\text { Deleted }\end{array}$ & $\begin{array}{c}\text { Scale Variance if Item } \\
\text { Deleted }\end{array}$ & \multicolumn{2}{|c|}{$\begin{array}{c}\text { Corrected Item-Total } \\
\text { Correlation }\end{array}$} \\
\hline Y.1 & 16,57 & 6,732 &, 801 \\
Y.2 & 16,62 & 6,501 &, 879 \\
Y.3 & 16,52 & 6,697 &, 860 \\
Y.4 & 16,52 & 6,959 &, 715 \\
Y.5 & 16,49 & 6,899 &, 682 \\
\hline
\end{tabular}

Berdasarkan data dari tabel diatas, semua item pertanyaan mempunyai nilai Corrected Item-Total Correlation > dari 0,3

b. Uji Reliabilitas

Uji Reliabilitas bertujuan untuk menguji konsistensi alat ukur (instrumen) yang digunakan,

Adapun hasil uji validitas pada pengujian ini untuk masing-masing variabel reliabel jika memiliki alpha > 0,60. adalah sebagai berikut:

Sedangkan Uji Reabilitas Sebagai berikut: $\quad$ Tabel 2

Uji Reabilitas

\begin{tabular}{|l|c|l|}
\hline \multicolumn{3}{|c|}{ Validitas } \\
\hline Variabel & $\begin{array}{c}\text { Cronbach } \\
\text { Alpha }\end{array}$ & Ket \\
\hline $\mathrm{X} 1$ & $0.741>0.6$ & Reliabel \\
\hline
\end{tabular}




\begin{tabular}{|l|l|l|}
\hline $\mathrm{X} 2$ & $0.911>0.6$ & Reliabel \\
\hline $\mathrm{Y}$ & $0.916>0.6$ & Reliabel \\
\hline
\end{tabular}

Sumber : SPSS diolah

3. Uji Asumsi klasik

a. Uji Multikolinieritas

Tabel 3

Uji Multikolinieritas

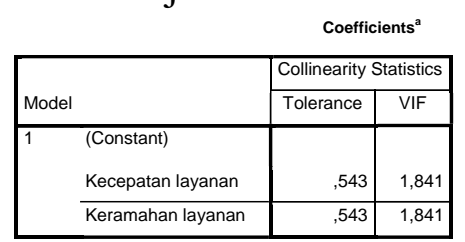

Dari tabel diatas menunjukkan bahwa nilai Variance Inflation Factor (VIF) dari masing-masing variabel independen tidak memiliki nilai yang lebih dari 10 sehingga dapat disimpulkan regresi dalam penelitian tidak mendukung multikolonieritas

b. heterokedastisitas

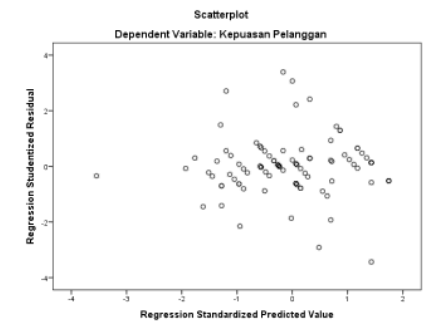

Gambar 1.heterokedastisitas

Gambar diatas penyebaran data menyeluruh pada sampel dan menyebar diatas dan dibawah angka nol pada sumbu Y maka tidak terdapat heterokedastisitas. c. Uji autokorelasi

Tabel 4 uji Autokorelasi

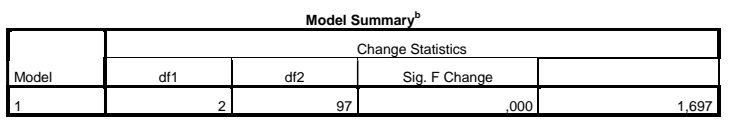

a. Predictors: (Constant), Keramahan, Kecepatan layanan

b. Dependent Variable: Kepuasan Pelanggan

Dari hasil pengujian dengan menggunakan uji Durbin Watson (DW) atas residual persamaan regresi diperoleh angka $\mathrm{d}$ hitung sebesar 1,697, sedangkan dari tabel Durbin Watson (DW) dengan signifikan 0,00 dan $\mathrm{df} 1=2$ dan $\mathrm{df} 2=97$ maka diperoleh nilai $\mathrm{dU}=1,601$.

Karena nilai DW $(1,697)$ berada pada daerah diantara $\mathrm{dU}(1,601)$ dan $4-\mathrm{dU}$
$(1,731)$ atau $\mathrm{dU}<\mathrm{DW}<(4-\mathrm{dU})(1,601<$ $1,697<1,731)$. Sehingga dapat disimpulkan bahwa tidak terjadi autokorelasi pada data dalam pengamatan. d. uji normalitas

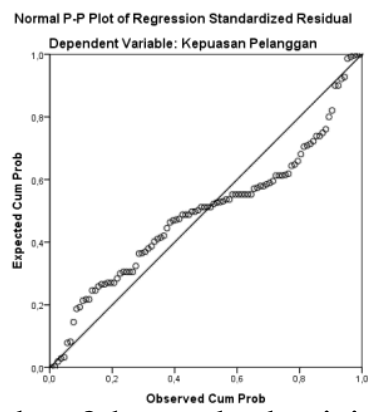

Gambar 2.heterokedastisitas

Dari gambar diatas menunjukkan bahwa gambar mengikuti garis melintang sehingga dapat dikatakan data berdistribusi normal

\section{Uji Analisis Regresi}

Bentuk persamaan pengaruh variabel $\mathrm{X}$ terhadap variabel $\mathrm{Y}$ adalah sebagai berikut : $\quad$ Tabel5 Analisis Regresi

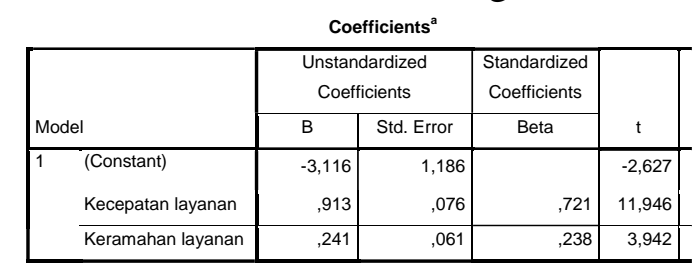

$\mathrm{Y}=-3,116+0,913 \mathrm{X} 1+0,241 \mathrm{X} 2$

Hasil persamaan regresi berganda tersebut di atas memberikan pengertian bahwa:

a. Nilai konstanta sebesar -3,116, penjelasan tersebut dapat diartikan bahwa jika tidak dipengaruhi oleh variabel bebas, yaitu Kecepatan Layanan dan Keramahan layanan, maka Kepuasan Pelanggan dalam minum kopi di rumah kopi Lamongan tidak akan mengalami perubahan (konstan)

b. b1 (nilai koefisien regresi X1) sebesar 0,913 mempunyai arti bahwa jika Kecepatan layanan (X1) pada Rumah kopi Lamongan meningkat 1 satuan, maka y akan meningkat sebesar 0,913satuan dengan syarat X2 Konstan. 
c. b2 (nilai koefisien regresi X2) sebesar 0,241mempunyai arti bahwa jika Keramahan layanan layanan(X2) pada Rumah kopi Lamonganmeningkat 1 satuan, maka y akan meningkat sebesar 0,241 satuan dengan syarat X1 Konstan.

d. Berdasarkan persamaan regresi tersebut, faktor yang paling dominan dalam mempengaruhi Kepuasan Pelanggan adalah Kecepatan layanan, terbukti dengan nilai koefisien regresinya yang paling besar yaitu sebesar 0,913 .

\section{Uji T}

a. . 1. Berdasarkan hasil perhitungan yang telah dilakukan Pengaruh Kecepatan layanan terhadap Kepuasan Pelanggan ditunjukkan dengan nilai $\mathrm{t}$ hitung sebesar 11,946, sedangkan $\mathrm{t}$ tabel ditentukan dengan $\mathrm{df}=\mathrm{n}-\mathrm{k}-1$ ) (100-2-1) maka diperolah nilai $\mathrm{t}$ tabel sebesar 1.660 karena 11,946>1,660 yang berarti $\mathrm{t}$ hitung lebih besar dari $\mathrm{t}$ tabel Sehingga dapat dikatakan ada pengaruh yang signifikan antara Kecepatan layanan terhadap Kepuasan Pelanggan secara parsial dalam minum kopi di rumah kopi Lamongan hipotesis terbukti.

2. Berdasarkan hasil perhitungan yang telah dilakukan Pengaruh Keramahan layanan terhadap Kepuasan Pelanggan ditunjukkan dengan nilai $t$ hitung sebesar 3,942, sedangkan t tabel ditentukan dengan $\mathrm{df}=\mathrm{n}-\mathrm{k}-1)(100$ 2-1) maka diperolah nilai $t$ tabel sebesar 1.660 karena 3,942>1,660 dan nilai signifikasinya sebesar $0,000<$ 0,05 . Sehingga dapat dikatakan ada pengaruh yang signifikan antara Keramahan layanan terhadap Kepuasan Pelanggan secara persial dalam minum kopi di rumah kopi di lamongan, Hipotesis terbukti.

\section{Uji F}

Tabel 6

Ujii F

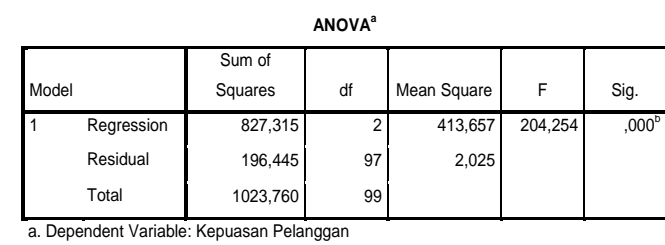

diperoleh nilai $\mathrm{F}$ hitung adalah sebesar 204,254 dengan hasil signifikasinya sebesar 0,000 , sedangkan degree of freedom pada angka 2 dan 97 dalam tabel $\mathrm{F}$ tabel diperoleh nilai sebesar 3,09 sehingga nilai $F$ hitung sebesar 204,254 > nilai $\mathrm{F}$ tabel $=3,09$ (signifikan). Hal ini dapat diartikan bahwa pengaruh antara Kecepatan dan Keramahan layanan secara bersama-sama mempunyai pengaruh yang signifikan terhadap Kepuasan Pelanggan dalam minum kopi di rumah kopi Lamongan.

7. Koefisien Determinasi

Tabel 7 Koefisien Determinasi

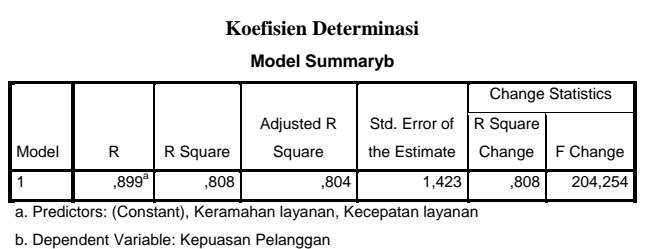

Dengan nilai Adjusted R Square (R2) yaitu sebesar 0,804 menggunakan R2 karena variabel bebas dalam penelitian ini lebih dari 1, dalam hal ini dapat diartikan bahwa Kepuasan Pelanggan mampu dijelaskan oleh Kecepatan layanan dan Keramahan layanan dengan nilai sebesar $80,4 \%$, sedangkan sisanya sebesar 19,6\% dijelaskan oleh variabel lain yang tidak diteliti dalam penelitian ini.

\section{SIMPULAN DAN SARAN}

Berdasarkan hasil penelitian pada pembahasan, maka ditarik beberapa simpulan sebagai berikut:

1. Dari hasil penelitian yang telah dilakukan dapat diketahui bahwa variabel kecepatan layanan (X1) mempunyai pengaruh yang signifikan secara parsial terhadap variabel terikat 
yaitu kepuasan pelanggan (Y). Variabel keramahan layanan (X2) mempunyai pengaruh signifikan secara parsial terhadap variabel terikat yaitu kepuasan pelanggan (Y) yang minum kopi dirumah kopi Lamongan.

2.Dari hasil penelitian yang telah dilakukan dapat diketahui bahwa variabel kecepatan layanan dan keramahan layanan mempunyai pengaruh yang signifikan dan bersamasama (simultan) terhadap variabel terikat yaitu kepuasan pelanggan kopi.

3.Dan diketahui variabel kecepatan layanan (X1) memiliki pengaruh yang lebih dominan, sehinggan dugaan peneliti terbukti.

\section{Saran}

Adapun saran-saran tersebut adalah sebagai berikut :

1. Mengingat faktor keceatan merupakan faktor yang dominan pengaruhnya terhadap tingkat kepuasan konsumen, hendaknya dalam mengambil kebijaksanaan pemasaran selalu mempertimbangkan perubahan prilaku konsumen, sehingga pelayanan yang diberikan dapat membuat konsumen merasa puas. Hal ini dapat dilakukan dengan meningkatkan kecepatan layanan terhadap kepuasan konsumen. Karena setiap konsumen yang datang ke dirumah kopi Lamongan ingin mendapatkan perlakuan dan pelayanan yang cepat ,baik dan memuaskan.

2. Untuk membentuk persepsi konsumen yang baik tentang dirumah kopi Lamongan maka kualitas pelayanan perlu mendapat perhatian lebih. Hal ini bertujuan untuk memberikan kesan atau pengalaman yang mendalam bagi konsumen tentang pelayanan dirumah kopi Lamongan dengan demikian konsumen akan berminat atau tertarik untuk minum kopi ulang.

3. Meskipun diketahui bahwa faktor kecepatan merupakan faktor yang dominan pengaruhnya terhadap kepuasan konsumen, namun faktor yang lain seperti faktor keramahan layanan tidak boleh diabaikan begitu saja.

\section{DAFTAR PUSTAKA}

Atmawati dan Wahyudin. 2004. "Analisis Pengaruh Kualitas Pelayanana terhadap Kepuasan Konsumen pada Matahari Departement Store di Solo Grand Mall'. Jurnal Ekonomi Sumber Daya. Vol 5 No. 1.

Dimyati, Tjuju, Tarliah,2012. Operation Research Edisi Kedua. PT. Sinar Baru Algesindo, Bandung.

Griselda, Gretel dan Panjaitan, tagor muda. 2007. "Analisis Kualitas Layanan Terhadap Kepuasan Konsumen Restoran Pulau dua". Derema Jurnal Manajemen. Vol. 2 No.1.

Imam Ghozali, 2012, Analisis Multivariant SPSS : Undip, Semarang.Harbani Pasolong ,2012

Kuswara 2009, Pedoman Bagi Personalia, PT. Pustaka Binaman Pressindo, Jakarta,

Kotler, Philip dan Keller, Kelvin Lane. 2010. Manajemen Pemasaran. Edisi Ketiga belas. Jilid 2. Erlangga. Jakarta.

Kotler, Philip. 2013. Manajemen Pemasaran. Edisi Bahasa Indonesia. Jilid 2. PT Prenhallindo. Jakarta.

Lupiyoadi, Rambat dan Hamdani. 2012. Manajemen Pemasaran jasa. Edisi Kedua.Salemba empat. Jakarta.

Moenir,2010. Penerapan Produktivitas Dalam Organisasi, Penerbit Alumni Bumi Aksara, Jakarta.

M.Nazir, 2011, Metodologi Penelitian PT Ghalia Indonesia Bogor 
Mustaniroh, Siti Asmaul ,dkk. 2010. "Penilaian Kepuasan Konsumen terhadap Kualitas Pelayanan Menggunakan Metode Servqual (service quality) (Studi kasus pada "waroeng X Cab. Soeekarno-Hatta Malang)" Jurnal Teknologi Pertanian Vol. 11 No. 3

Mei Mei Lau Ronnie Cheung Aris Y. C. Lam Yuen Ting Chu 2013),Measuring Service Quality in the Banking Industry: A Hong Kong Based Study akses http://www.cmrjournal.org/article/view/11060/p df

Notoatmodjo,S.2012. Metodologi Penelitian Kesehatan. Jakarta: Rineka Cipta

Nilawati, dan Indriani. 2012. "Pengaruh Atribut Produk dan Referensi Komunitas Terhadap Minat Beli Ulang pada Kafe di Lamongan" Jurnal Manajemen. Volume 1. Nomor 2.

Nugroho, dan Puriarta. 2011. "Analisis Kualitas Pelayanan Terhadap kepuasan Pasien Kamar Rawat Inap Kelas 2 pada Rumah Sakit Islam Jakarta". AKTIVA, Volume 4 Nomor 7.

Navri. 2011. "Perbandingan Kualitas layanan berdasarkan kategori Restoran : Studi Kasus di Badung Bali". Jurnal Administrasi Bisnis Vol.7 No.1.

Poniman, dan Kusmardi. 2011 "Pengaruh Kualitas Pelayanan Terhadap Kepuasan Siswa pada Sekolah menengah kejuruan Negri 4 Klaten". Jurnal STIE. Edisi 1 No.1

Priyatno, Duwi, 2010. Paham Analisa Statistik Data dengan SPSS. Cetakan Pertama. Yogyakarta : Mediakom
Sugiyono.2010.Metode Penelitian

Pendekatan Kuantitatif,

Kualitatif, dan R\&D. Penerbit

Alfabeta. Bandung.

Sugiyono. 2012 Statistika Untuk

Penelitian. Bandung:

ALFABETA Wulandari, Indah

Sevia. 2012. "Analisis Pengaruh

Kualitas Pelayanan Terhadap

Kepuasan Konsumen pada

Kedai Kopi Starbucks Cabang

Alam Sutera". Jurnal ekonomi

Manajemen Universitas

Gunadarma.

.Tjiptono, Fandy. Chandra, Gregorius dan Adriana, Dadi. 2008. Pemasaran Strategik. Andi. Yogyakarta.

Widya Citami Putri,2013 Pengaruh

Kualitas Pelayanan Dan

Kepuasan Terhadap Loyalitas

Pasien Rawat Jalan Dan Rawat

Inap Rumah Sakit Otorita

Batam. Skrisi Program Studi

Manajemen Fakultas Bisnis Dan

Manajemen, Universitas

Widyatama Bandung

online

https://rumah-kopi.com/profil akses 2507-2016 